\title{
Generation of Value of a Brazil Fashion Industrial Cluster: A Systemic Analysis
}

\author{
Rosiane Serrano ${ }^{1 *}$, Maria Isabel Wolf Motta Morandi $i^{2}$, Douglas Rafael Veit ${ }^{2}$, \\ Ricardo Brandão Mansilha, Daniel Pacheco Lacerda²
}

\begin{abstract}
Companies that organize themselves in industrial clusters seek to amplify their capacity to generate value. However, the process of analyzing, creating and delivering value has been presented in a fragmented way. There is a lack of studies and systemic understanding. This study aims to analyze systemically the drivers and barriers for generation of value in fashion industrial cluster in the Southern Region of Brazil. The research method used to conduct this study is case study with a qualitative approach. The six elements that compose the process of analyzing, creating and delivering value were used to identify drivers and barriers for generation of value in industrial clusters and development to knowledge on clusters. The variables were interrelated the results them and formed the systemic structure. The analysis allowed concluding that the elements for generation of value described in the literature are present in the study units and it possible use this element for knowledge from clusters. However, it is necessary to analyze them systemically to obtain the desired results. This study evidenced a conceptual misalignment by participating companies regarding the true role of an industrial cluster. Strengthening among peers, in the form of exchanges of experiences and synergy among companies, does not happen in a satisfactory way. This relation among companies should be highlighted so that the cluster results are improved.
\end{abstract}

Keywords: Industrial cluster; Generation of value; Systemic analysis; Drivers and barriers.

Submitted: July $1^{\text {st }}, 2019$ / Approved: May $17^{\text {th }}, 2020$

\section{Introduction}

Clusters are geographic concentrations formed by interconnected companies, specialized service providers, correlated industries and associated institutions in a given context, these companies cooperate and compete with each other (Porter, 2000). Thus, clusters are related to the creation of network relationships (Hsu, Lai, \& Lin, 2014) that aim to obtain a competitive advantage based on location and complementarity of products and services (Sellitto \& Luchese, 2018). Clusters also promote synergic benefits for companies inside the cluster by exploring scale economies (Ikram, Su, Fiaz, \& Rehman, 2018). Therefore, the grouping of companies into clusters allows companies to co-develop competencies to improve their market competitive advantage in the sectors they operate.

However, even if recent studies suggest that company leaders should consider clusters as one of the main sources of economic strength (Mudambi, Mudambi, Mukherjee, \& Scalera, 2017), joint actions that presume the sharing of knowledge, resources and innovative capabilities are considered a difficulty in the management of industrial clusters because companies are not always willing to share their knowledge, resources and capabilities (Niu, Miles, Bach, \& Chinen, 2012). Consequently, a cluster may be characterized as a systemic phenomenon that depends on the interaction between its members (Allen, Maguire, \& McKelvey, 2011).

IIn addition, cluster premises, which consist in the development of joint actions among companies and governmental and non-governmental institutions that support the structuring and the operation of the cluster, are not always followed. First, clusters are composed by companies with different settings. This makes knowledge flows difficult and depreciates the proposed activities, i.e., suggestions for big companies are not absorbed by small companies and vice versa. Secondly, better results proposed for organizations inside the cluster (Allen et al., 2011) take long to be identified. This promotes demobilization of companies inside the cluster. Thirdly, cluster participants unite by turning their essential knowledge and competences into tangible and intangible products that offer value to the other cluster participants (Wang, Lai, \& Hsiao, 2015). However, they are difficult to quantify. This reinforces, therefore, the systemic character of clusters (Capra, 1985).

In this sense, clusters may be analyzed systemically by considering the potential of value they generate for companies inside them. Such value go beyond "a minimum monetary cost attributed to the purchase or the manufacture of a product" (Lindgreen, Hingley, Grant, \& Morgan, 2012). This value takes into account existing relationships and possible limitations that hinder the growing of the company's potential. Therefore, the way the participating company perceives what is offered by the other cluster companies was defined as value, in other words, what has been produced, delivered and consumed. Thus, value is a consequence of a process that begins with the offer of some differential feature by the supplier for the client (Lindgreen \& Wynstra, 2005). Value can be generated from three distinct perspectives: ability to compete and respond to the challenges of the industry environment, ability to exploit relational skills and ability to understand and respond to customers (Kähkönen \& Lintukangas, 2012). In addition, value can be understood as a process that consists of analyzing, creating and delivering value (Lindgreen et al., 2012) for the company participating in the cluster.

(1) Instituto Federal de Educação, Ciência e Tecnologia do Rio Grande do Rio Grande do Sul- Campus Erechim, Erechim, RS, Brazil.

(2) Production and System Engineering Graduate Program, Universidade do Vale do Rio dos Sinos, São Leopoldo, RS, Brazil.

(3) Instituto Federal Farroupilha - Campus Frederico Westphalen, Frederico Westphalen RS, Brazil.

Corresponding author: rosiane.serrano@erechim.ifrs.edu.br

ISSN: 0718-2724. (http://jotmi.org)

Journal of Technology Management \& Innovation @ Universidad Alberto Hurtado, Facultad de Economía y Negocios. 
This study aims to analyze systemically drivers and barriers for generation of value in an industrial cluster. The cluster analyzed is of the fashion segment and this situated in Southern Region of Brazil. The choice of this sector is justified because the Brazilian textile chain produced approximately 1.8 million tons in 2015, reaching US\$ 39.4 billion in production value (IEMI - Inteligência de Mercado, 2016). Worldwide, Brazil is the fourth largest clothing producer and the fifth producer among textile manufacturers, mainly, because it employs 1.6 million people (Associação Brasileira da Indústria Têxtil e de ConfecçãoABIT, 2015). Moreover, this segment comprises 32 thousand industries, among which $80 \%$ are small and medium companies (with over five employees) distributed throughout Brazil (IEMI, 2016). However, clusters do not comprise all textile companies in Brazil. Thus, making efforts to understand this sector may result in effective solutions with view a competitive advantage of the actors that comprise the cluster (Serrano, 2013).

The research method used to conduct this study is case study with a qualitative approach. This research approach allows understanding and developing a complex situation taking into account the variables in the system and their non-linear behavior (Schneider \& Hoffmann, 2011). The method is adequate to the characteristics of the cluster studied. The dates was collected from of six elements proposed by Lindgreen et al. (2012). The elements were used to identify drivers and barriers of generation of value in industrial clusters and development to knowledge on clusters. The data resulting from the case study were interrelated and formed the systemic structure. It should be noted that the systemic approach enables identifying key system variables to which efforts must be concentrated in order to increase the companies' performance (Ford \& Sterman, 1998; Zare Mehrjerdi, 2012). Furthermore, the identification of drivers and barriers facilitate the understanding of the cluster complexity and promote the creation of operational policies leading to effective changes (Sterman, 2002).

Given these initials information on the context of this research, the theoretical references on the elements for analysis, creation and deliver of value are presented below. Subsequently, the methodology used, the results of the case study, the systemic analysis, the managerial implications and the final considerations are presented.

\section{Elements for analysis, creation and deliver of value in industrial clusters}

As globalization promoted an opening of markets in new countries, it also exerted influence on the location of several industrial locations, promoting the concentration of particular segments of production on certain geographic locations (Marshall, 1920). Thus, the connection with service specialized providers, correlated industries and associated institutions, which cooperate and compete with themselves (Porter, 2000), started to foster economic advantages arising from proximity (Lei \& Huang, 2014) and generated scale economies due to co-location (Kähkönen \& Lintukangas, 2012). Consequently, the concentration of organizations into industrial clusters became relevant to the development of cities (Zeng, Liu, Tam, \& Shao, 2008). They contribute to the improvement of competitiveness of local companies inside them (Fiol, Tena, \& García, 2011).
Consequently, the interest in developing industrial clusters has been promoted by development agencies and political decision-makers (Karlsen, 2013). First, due to the creation of collective opportunities of efficiency, which derive from common actions (Carpinetti, Galdámez, \& Gerolamo, 2008; Hsu et al., 2014), the creation of clusters is one of the main strategies for a sustainable development of companies (Hsu et al., 2014). Secondly, joint actions may help to consolidate cooperation, articulation and exchange of information among the participants of clusters and promote a culture of continuous innovation, contributing to collective development (Carpinetti et al., 2008). Thirdly, clusters provide better opportunities to develop network relationships with other close companies inside the cluster (Lei \& Huang, 2014). This leads to a network of contacts based on collaboration and knowledge and will make location a less significant factor (Kähkönen \& Lintukangas, 2012).

However, Liao (2010) described that only clusters with an abundance of tangible or intangible resources can improve the development of companies participating in them only if such companies inter-organize and create trust to improve their development. There must therefore be an interaction among cluster participants (Karlsen, 2013) so that advantages from industrial clustering, such as specialized services easily accessible by suppliers of raw materials, which reduces transportation costs for companies participating in the cluster (Carpinetti et al., 2008; Marshall, 1920), be identified. Thus the an interaction between different actors aiming to produce value, and a collaboration are significant factors (Wang et al., 2015).

Kähkönen e Lintukangas (2012) reports that generation of value produced by network activities provide a greater efficiency for businesses than individually developed activities. However, not all cluster organizations are engaged with joint interaction, this evidences that there are other factors shaping the value relations in this environment (Lindgreen et al., 2012). Therefore, systemically analyzing drivers and barriers for generation of value may help to manage the collective efficiency of a cluster.

In this sense, Lindgreen et al. (2012) identified three steps organizations and marketing professionals use to analyze, create and deliver value. The analysis step focuses on how customers evaluate value. The creation step involves the use of studies to develop products or services. Finally, the delivery step is related to processes that offer the best value for a given customer (Lindgreen \& Wynstra, 2005). From analysis, creation and delivery, six potential research elements were identified to measure generation of value, namely value proposition, relationship, value metrics, internal capabilities, innovation and time horizon and tactical focus (Lindgreen et al., 2012).

Value proposition is defined by competition and determines the direction the company will take to add value to its products and services (Lindgreen et al., 2012; Polo Penã, Frías Jamilena, \& Rodríguez Molina, 2017). As an example, there are brands seeking to offer differentiation in a sustainable way to compete in the market 
and to be global leaders (Beverland, Napoli, \& Lindgreen, 2007). They offer services seeking to increase consumer satisfaction, improve manufacturing and give it credibility (Kowalkowski, Witell, \& Gustafsson, 2013). The steps creation of value means structuring actions related to the conception of acquisition, accumulation and investment of resources to create a portfolio of products and services that meet the customers' needs (Lindgreen et al., 2012). Products offer, in addition to economic and functional characteristics, an association with intangible goods, such as experience (Beverland et al., 2007). For value delivery, there are processes focused on the identification and development of the market, sales and delivery of the good offered (Garriga, 2014). The combination of products and services unique to each customer is sought (Battaglia et al., 2014) by betting on intangible values such as reputation, innovation, service and strategic advice (Lindgreen, Beverland, \& Farrelly, 2010). Thus, a high-value delivery to customers will reinforce the competitive advantage of the organization, making it difficult for competitors to imitate such capabilities (Lindgreen, Palmer, Vanhamme, \& Wouters, 2006).

The element relationship is identified when there are exchanges between the parties aiming an organization of operation, learning and adaptations for the development of new solutions (Lindgreen et al., 2012). The collaborative work to add value is considered timely and relevant to the different actors involved (Wang et al., 2015). Thus, the analysis step verify the interactions between the companies aiming to maintain relationships in the future (Lindgreen et al., 2012). Creation of value is developed jointly through a correlation between parties. Collaboration is a crucial aspect for the management of product supply (Kähkönen \& Lintukangas, 2012). Finally, delivery identifies which relationships are important for current and future relationships independent of market, going beyond the product or the service offered (Lindgreen et al., 2012).

The metrics of value can be evaluated according to the interest of the beneficiary of the product or service (Kähkönen \& Lintukangas, 2012). Intangible characteristics, such as experience and reliability, are associated with product quality and performance (Beverland et al., 2007). Thus, metrics are established to map resources and understand the value of analyses (Lindgreen et al., 2012). This improves competitive positioning and, consequently, the image of the brand in face of competitors at a collective and individual level (Coutelle-Brillet, Riviere, \& des Garets, 2014). However, there are difficulties in measuring the intangible elements of value since they differ according to the moment and the context. Something that was considered as a value in the past is not necessarily considered a value in new contexts. Finally, value is only really perceived after the solution offered is used in product or service (Corsaro, 2014).

The element internal capabilities considers intangible and tangible as the main facilitators of generation of value (Kähkönen \& Lintukangas, 2012). In this sense, the generation of value occurs by collaboration, combination of resources, competences and capabilities. It is the central element for both parties involved to learn and understand about the context (Geraerdts, 2012). The interaction between companies aiming the development of products or innovative processes provides mutual benefits (Lindgreen et al. (2012), such as manufacturing credibility and consumer satisfaction (Hau \& Thuy, 2012; Kowalkowski et al., 2013). Innovation seeks to improve competitiveness and the image of the company taking interested parties into account in comparison with other companies that have different degrees of innovation (Coutelle-Brillet et al., 2014; Espino-Rodríguez, 2016). Innovations developed with partners increase the benefits for both parties involved in a process (Rodriguez, Doloreux, \& Shearmur, 2016).

Tactical focus and time horizon are related to the appropriate development of strategies for short or long-term transactions (Lindgreen et al., 2012). In markets with short life cycles, short-term strategies are appropriate as companies need to identify the right time to innovate products or services (Lindgreen et al., 2012), for example products developed as product families, which allow a greater variety and customization (Battaglia et al. 2014). The time horizon may be different for each type of relationship, that is, companies based on transactional relationships tend to temporarily interrupt ties, acting together at certain times of the year or at seasonal purchases (Lindgreen et al., 2012), or interacting to solve problems (Lacoste, 2012). Based on the description of the six potential elements to measure generation of value, a Table 1 was proposed. Thus, Table 1 shows factors taken into account to measure generation of value of industrial clusters. 
Table 1 - Synthesis of elements for generation of value in industrial clusters

\begin{tabular}{|c|c|c|}
\hline Element & Factor to be considered & Author \\
\hline \multirow{5}{*}{ Value proposition } & $\begin{array}{l}\text { Strategic directing for generation of value; } \\
\text { Structuring of actions to meet customer needs; }\end{array}$ & $\begin{array}{l}\text { (Lindgreen, Hingley, Grant, \& Morgan, 2012; Polo } \\
\text { Penã, Frías Jamilena, \& Rodríguez Molina, 2017) }\end{array}$ \\
\hline & $\begin{array}{l}\text { Development of differential products with sustainable concepts and economic and } \\
\text { functional characteristics; }\end{array}$ & (Beverland \& Lindgreen, 2007; \\
\hline & Identification and development of new markets; & attedCitation":"(Garriga, 2014 \\
\hline & Combination of products and services to each customer; & (Battaglia et al., 2014) \\
\hline & Appropriation of intangible values for value adding; & $(\mathrm{L}$ \\
\hline Relationship & $\begin{array}{l}\text { Development of collaborative work; } \\
\text { Management of product offers developed in a collaborative way; }\end{array}$ & $\begin{array}{l}\text { (Kähkönen \& Lintukangas, 2012; Wang, Lai, \& } \\
\text { Hsiao, 2015) }\end{array}$ \\
\hline Value metrics & Identification of the appropriate method for value measurement; & (Kähkönen \& Lintukangas, 2012) \\
\hline \multirow{4}{*}{ Internal capabilities } & Combination of tangible and intangible assets; & (Kähkönen \& Lintukangas, 2012) \\
\hline & Collaboration and combination of resources, skills and capabilities; & (Geraerdts, 2012) (Kähkönen \& Lintukangas, 2012) \\
\hline & Strengthening of manufacturing credibility through service mechanisms; & (Kowalkowski, Witell, \& Gustafsson, 2013) \\
\hline & Interaction for the development of products and processes aiming mutual benefits; & (Lindgreen et al., 2012) \\
\hline \multirow[b]{2}{*}{ Innovation } & Improvement of competitiveness; & (Coutelle-Brillet et al., 2014; Espino-Rodríguez, 2016)6 \\
\hline & Development of innovative products and processes with partners; & $\begin{array}{l}\text { (Lindgreen et al., 2012; Rodriguez, Doloreux, \& } \\
\text { Shearmur, 2016) }\end{array}$ \\
\hline $\begin{array}{l}\text { Tactical focus and } \\
\text { Time horizon }\end{array}$ & $\begin{array}{l}\text { Development of strategies for short- or long-term transactions; } \\
\text { Joint action for certain actions; }\end{array}$ & (Lindgreen et al., 2012) \\
\hline
\end{tabular}

Thus, the analysis, creation and deliver of value in industrial clusters, considering the elements presented, are important knowledge methods to manage institutions. Therefore using knowledge and understanding of existing factors, cooperation among interested parties can be promoted (Carpinetti et al., 2008). They also foster maintenance and shortening of information flow and human resources in the long term and stress knowledge as an innovation advantage (Fiol et al., 2011; Hsu et al., 2014). Therefore, the elements used to identify drivers and barriers of generation of value in industrial clusters can auxiliary in their future development.

\section{Methodological Procedures}

This study used the qualitative approach. This approach, which is appropriate for analyses based on illustrative cases (Sobh \& Perry, 2006) or when the researcher seeks to organize ideas on a complex interest situation (Sellitto, Pereira, Marques, \& Lacerda, 2018). In addition, this research is exploratory, as it develops a systemic analysis of possible drivers and barriers for generation of value in an industrial cluster from results arising from a case study. An exploratory research assists in the formulation of a problem or in its definition, identification of action alternatives and criteria obtaining without needing to elaborate hypotheses to be tested (Hair Jr, Celsi, Money, Samouel, \& Page, 2011). Figure 1 shows activities developed by the researchers.

Figure 1 - Work method

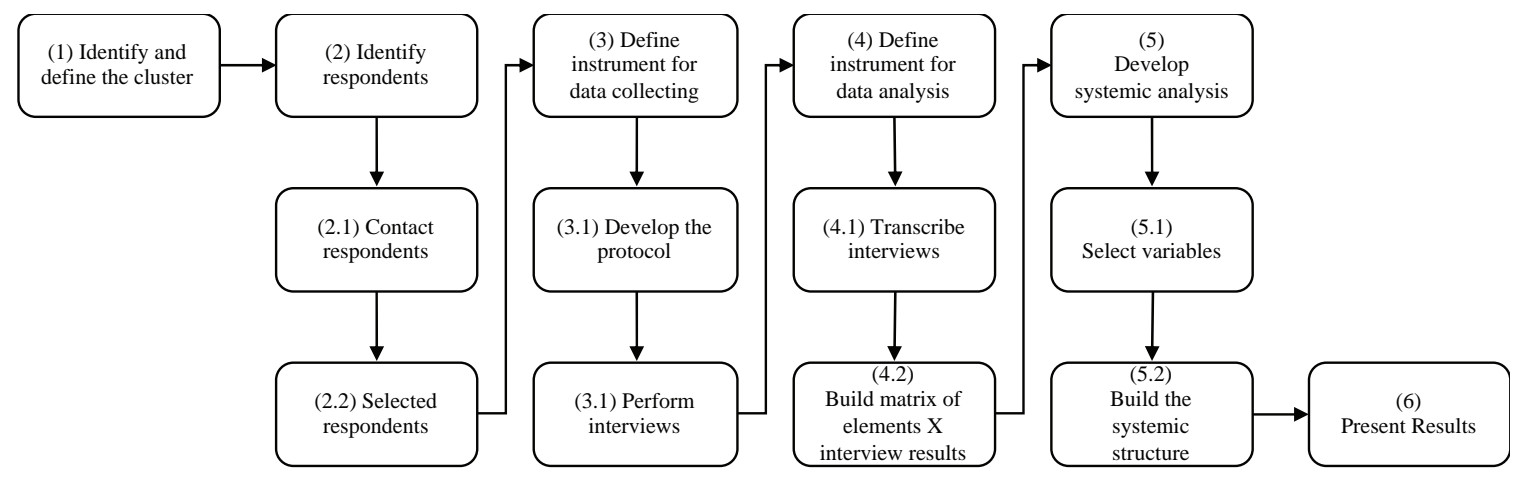

ISSN: 0718-2724. (http://jotmi.org)

Journal of Technology Management \& Innovation @ Universidad Alberto Hurtado, Facultad de Economía y Negocios. 
The first activity was to identify and define the cluster (1). The industrial cluster under study had its legal status established in 2007 aiming to promote the development of the fashion sector by creating and consolidating a differential competitiveness and a regional identity that serve as a reference for the fashion market through innovation and production. The selection of this cluster, located in the Southern Region of Brazil (Rio Grande do Sul), was due to the inter- est in analyzing systemically the drivers and barriers for generation of value from a set of micro and small companies which are potential suppliers among themselves and also suppliers to medium and large companies in the fashion industry (Manfredini et al., 2013). These companies form a cluster acknowledged for the production of fashion in Brazil and the cluster comprises twenty-five organizations, illustrated in Figure 2.

Figure 2 - Representation of the fashion industry cluster

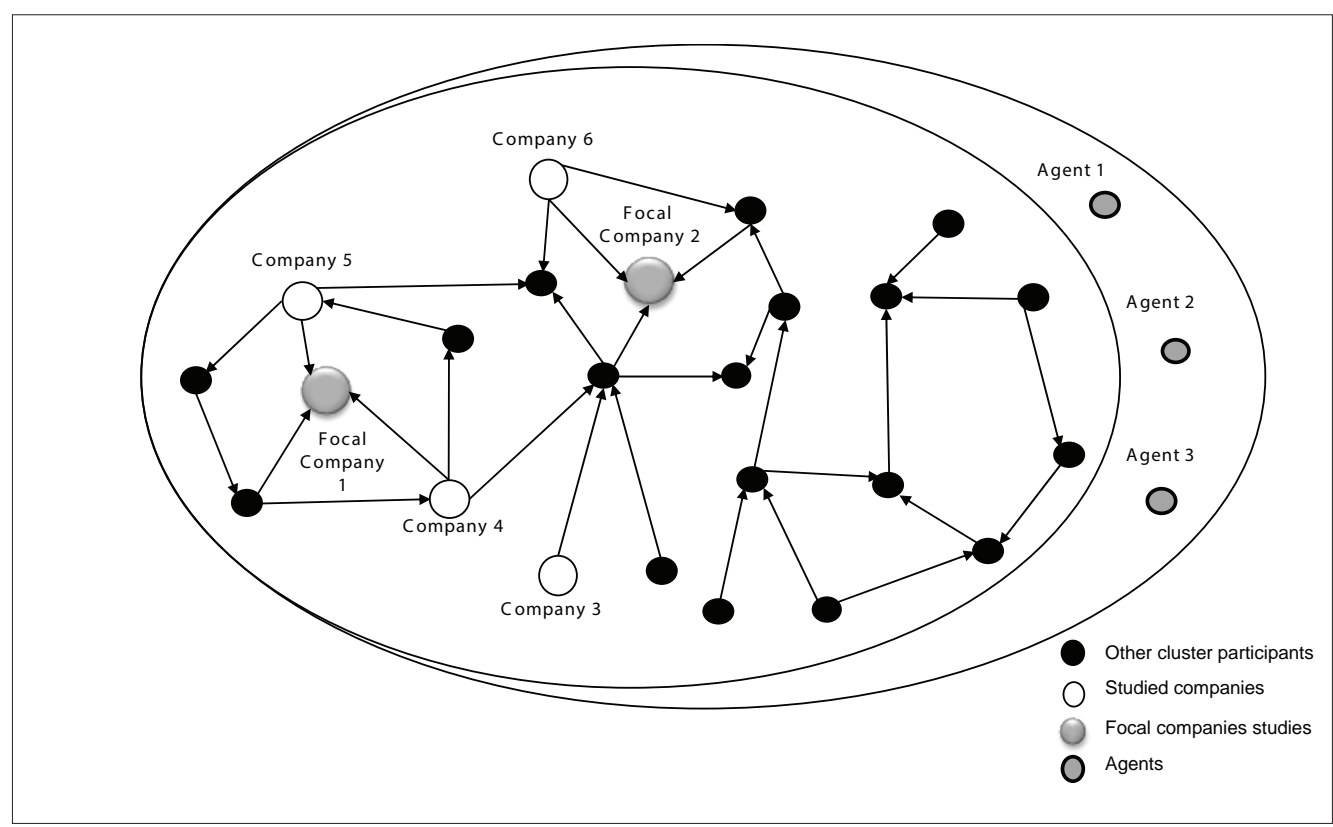

The step of identifying respondents (2) was conducted through information provided by the cluster, following the Figure 2. However, the selection of the sample considered as criteria the relevance of organizations in the decision-making processes of the cluster actions, as pointed out by the cluster managing institution, and the availability for answering the questionnaire. Thus, participated four manufactu- ring companies, two focal manufacturing companies, three agents active in the cluster, the managing institution of the cluster, the supporting university and a social institution focused on technical training and disposal of garments' waste were included. The characterization of organizations and the profile of respondents are shown in Table 2. The respondents were managers and/or owners of the organizations.

Table 2 Characterization of the organizations and profile of respondents

\begin{tabular}{|c|c|c|c|c|c|}
\hline Interviewee & Company & Segment & Size & Position & Time in Company \\
\hline 1 & Focal Company 1 & Underwear & Medium & Cluster Director & 24 years \\
\hline 2 & Focal Company 2 & Night clothes & Medium & Director & 25 years \\
\hline 3 & Company & Textile & Large & Cluster Founder & 29 years \\
\hline 4 & Company & Clothing & Small & Director & 15 years \\
\hline 5 & Company & Underwear & Small & Owner & 53 years \\
\hline 6 & Company & Working clothes & Small & Director & 20 years \\
\hline 7 & Agent 1 & Governance & - & Cluster Manager & 10 years \\
\hline 8 & Agent 2 & University & - & Researcher & 19 years \\
\hline 9 & Agent 3 & Capacity & - & $\mathrm{CEO}$ & 06 years \\
\hline
\end{tabular}

The cluster participants have defined activities. The managing agent is the articulator of actions, promotes the grouping of companies, foments an alignment among all involved actors and also forms technical groups. Such technical groups - divided into design, marketing, sales, qualification and technology - are composed of participants from companies, institutions and agents seeking the development of innovations for the cluster. The companies then act as members of technical groups, and on the referral of priority actions. The other agents, that is, teaching and research institutions, participate in the cluster through training, design studies, market and promotion. 
The data collection instrument (3) defined for this research were personal interviews conducted using a semi-structured script and direct observation. To organize data collection and perform the subsequent analysis, the theoretical elements shown in Table 1 were used. Table 3 presents these elements, the objective of each element and the questions asked to the interviewees. They were recorded. All interviews together lasted four hours and thirty minutes.

Table 3 - Topics investigated in each element

\begin{tabular}{l|l|l}
\hline \multicolumn{1}{c|}{ Element } & \multicolumn{1}{c}{ Objective investigated } & \multicolumn{1}{c}{ Questions } \\
\hline Value proposition & Investigate how the value proposition in the cluster is developed; & $\begin{array}{l}\text { 1. What does the customer value in the product offered and how } \\
\text { is this value offered? }\end{array}$ \\
\hline Relationship & Identify how the value relationship of cluster components works; & $\begin{array}{l}\text { 2. How are the relationships with customers, other suppliers } \\
\text { and cluster agents? }\end{array}$ \\
\hline $\begin{array}{l}\text { Value metrics } \\
\text { Internal capabilities }\end{array}$ & Investigate how the cluster monitors the performance of its actions; & $\begin{array}{l}\text { 3. How does the cluster monitor its performance/impact in face } \\
\text { of what is offered to cluster participants? }\end{array}$ \\
\hline $\begin{array}{l}\text { Innovation } \\
\text { Identify how the cluster shares and allocates resources; } \\
\text { horizon }\end{array}$ & Identify how the cluster develops innovation; & $\begin{array}{l}\text { 4. How is resource sharing organized and accomplished with } \\
\text { cluster participants, suppliers and agents? }\end{array}$ \\
\hline
\end{tabular}

Interview transcriptions comprise the process of data analysis (4). The transcriptions were organized in matrix contained the elements to be analyzed and the objectives of each element in rows (horizontally). In columns (vertical), the respondents' answers were compiled for comparison with the literature at a further stage. The matrix format is used to facilitate visualization and to allow a detailed analysis of the collected data (Miles, Huberman, \& Saldanã, 2014). The Appendix A shows an excerpt of the matrix containing the data classified and organized according to the elements identified in the literature. Section 4 presents the answers for each element considering the topics investigated and the synthesis of the drivers and barriers for generation of value.

Based on this matrix, the systemic analysis of (5) drivers and barriers for generation of value of an industrial cluster was conducted. By analyzing the results (Appendix A), the variables that influenced the elements in the cluster were listed and organized into a systemic structure. The development of the systemic structure followed the steps proposed by Morandi et al. (2014). The construction of the systemic structure used systemic language. It seeks to evidence the connections formed by variables that inter-relate, evidencing cause and effect relations. These variables may present direct or proportional relations (represented by continuous arrows), i.e., when A increases, (effect's cause), B increases (effect). The relations may be indirect, or inversely proportional (represented by dashed arrows), i.e., when A increases (effect's cause), B decreases (effect) (Serrano, Lacerda, Cassel, Rodrigues, \& Soares, 2017). Experts in Systemic Thinking and industrial clusters reviewed the systemic structure developed.

First, this systemic structure evidenced the relations among the various actors in the cluster. Later, drivers and barriers were identified. By conducting systemic analysis, a confrontation with literature is also conducted. Considering the systemic character of clusters in general and how the behavior of a system is determined by the structure of its relations (Kidwai \& Saraph, 2016; Senge, 2009), it was important to present the existing relations as a systemic structure. The activity 6 represents the results reported in this study.

\section{Systemic analysis of drivers and barriers for generation of value}

Based on the interview results (Appendix A), the variables presenting drivers and barriers of generation of value of the cluster under study were identified. Table 4 shows sentences that represent drivers and barriers considering the elements for generation of value in clusters. 
Table 4- Drivers and barriers for generation of value in industrial clusters

\begin{tabular}{|c|c|c|}
\hline Element & Driver & Barrier \\
\hline Value proposition & $\begin{array}{l}\text { Differentiation in product and process design; } \\
\text { Innovation actions such as events; } \\
\text { Diversity of projects; } \\
\text { Facilitator - the managing agent works as an articulator } \\
\text { Involvement of the cluster with demands; } \\
\text { Training in various areas; } \\
\text { Effectiveness of promoted actions; }\end{array}$ & $\begin{array}{l}\text { Development of projects that have a common goal; } \\
\text { Bureaucracy for project approval; } \\
\text { Not fully meeting the demands of the companies participating in } \\
\text { the cluster; } \\
\text { No differentiation between cluster participants and external com- } \\
\text { panies; } \\
\text { Directing of actions to specific companies; } \\
\text { Actions with different intensities; } \\
\text { Effective participation of stakeholders; } \\
\text { Complexity of demands; }\end{array}$ \\
\hline Value metrics & $\begin{array}{l}\text { Agents as inducers of proximity to companies; } \\
\text { Confidence; } \\
\text { Initiative actions; } \\
\text { Exchange of experience; } \\
\text { Proximity of agents to companies; }\end{array}$ & $\begin{array}{l}\text { Incipient participation of all members; } \\
\text { Ethics and coexistence; } \\
\text { Mistrust regarding possible copy of ideas and attempt to hire of } \\
\text { employees by competitors; } \\
\text { Little information exchange; } \\
\text { Difficult customer loyalty; }\end{array}$ \\
\hline Value metrics & Permanence in the cluster; & Lack of follow-up; \\
\hline Internal capabilities & $\begin{array}{l}\text { Formation of working groups; } \\
\text { Involvement for training; } \\
\text { Meetings for appropriation of capabilities; }\end{array}$ & $\begin{array}{l}\text { Dichotomous vision of the market; } \\
\text { Lack of internal capacity sharing; } \\
\text { Difficulty in interpreting the company's role in the cluster; }\end{array}$ \\
\hline Innovation & $\begin{array}{l}\text { Formation of technical groups; } \\
\text { Promotion of events; } \\
\text { Collectivism for the development of actions }\end{array}$ & $\begin{array}{l}\text { Broad actions focused on several segments; } \\
\text { Innovation actions developed only by agents are disclosed to the } \\
\text { companies participating in the cluster } \\
\text { Repetition of projects; }\end{array}$ \\
\hline $\begin{array}{l}\text { Tactical focus and } \\
\text { Time horizon }\end{array}$ & $\begin{array}{l}\text { Differentiation of product development; } \\
\text { Punctual and continuous actions. }\end{array}$ & $\begin{array}{l}\text { Low intensity of creation of innovations by companies; } \\
\text { Further punctual actions. }\end{array}$ \\
\hline
\end{tabular}

Following, the variables shown in Table 4 were inter-related, thus performing the systemic analysis. It was sought to understand how drivers and barriers for generation of value related in this cluster by evidencing cause and effect relations. The variables may present direct or proportional relations (represented by continuous arrows), that is, when A increases (cause of effect), B increases (effect). Relations may also be indirect or inversely proportional (represented by dashed arrows), that is, when $\mathrm{A}$ increases (cause of effect), B decreases (effect) (Serrano et al., 2017).

Therefore, the Figure 3 shows the systemic structure with relations the element "value proposition", the variable generating value for the customer influences competitiveness and consequently reverberate in cluster image and reputation and attractiveness, affecting the number of companies that may participate in the industrial cluster. Thus, the cluster managing agent acts as a facilitator by articulating the needs and demands of companies along with other agents involved, as expressed by the Interviewee 2: "The cluster acts as a link between suppliers and participating companies, that is, it helps companies to find suppliers that offer what companies need." In addition, the cluster propose value by translating needs and demands into products using innovative concepts, training courses, promotion of design projects, research and market research. The Interviewee 4 points out that the "delivery of cluster value to companies focuses on the performance of technical groups, which promote training courses, design projects and market prospecting".
However, the interviewees state that there is a difficulty in developing projects aligned with a common goal, that is, there is no unanimous view among cluster components, as it exposes Figure 3. Such a lack of unity is directly related to the different sizes of participating companies. Thus, the first barrier mentioned by interviewees was that actions have different effectiveness levels, varying according to company size. As Interviewee 1 stated: "The thoughts of companies participating in the cluster are divergent; it is difficult to manage the proposal and the development of common actions". In line with this, a dissatisfaction with the significant number of actions directed at small companies becomes evident. It is a feeling present in a significant part of the cluster.

Corroborating this, the Interviewee 8 pointed out that "the companies that participate in the cluster are small, making the environment for developing leverage actions more complex". This leads to the withdrawal of focal companies that do not feel represented and end up developing actions independently. Finally, the companies' immediate view of results of actions promotes a dichotomous view on their effectiveness. Specifically, companies consider bureaucracy in the development and approval of common projects as a barrier, which creates an innovation gap, as shown in Figure 3. This was mentioned by the Interviewee 9, who described that "it is not possible to develop specific training to meet the needs of a company, but of the cluster in general". 
Figure 3 Systemic structure - element "value proposition"

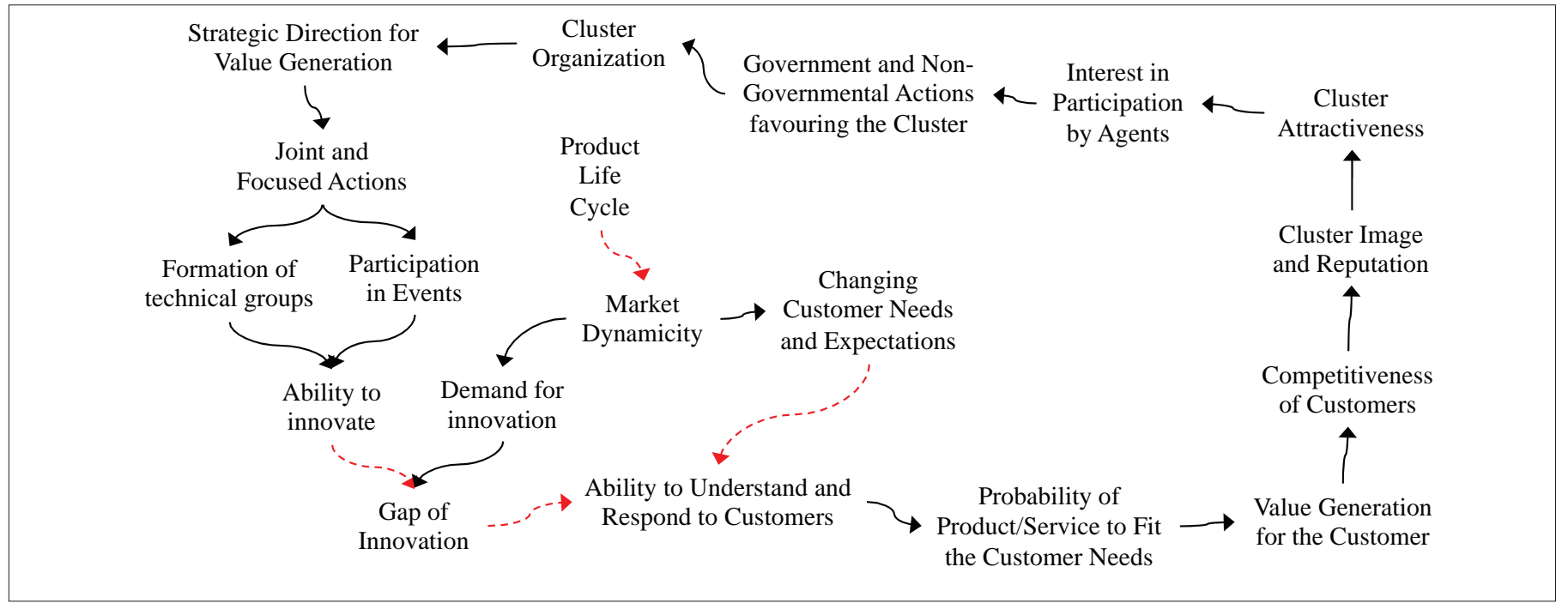

The second element of Figure 4, "relationship", evidenced that the greater the performance of the cluster managing agent, the greater the company dependence to that agent. This favors a decrease in the active participation of companies and a decreasing effect on cluster organization. This relation evidences that the cluster agent influences significantly cluster decisions. Many companies take advantage of such influence and do not participate actively in decisions. Agreeing to this, the Interviewee 3 states that "it is difficult to make companies participate in the developed actions". In addition, relationships and co- existence issues, such as the lack of trust regarding copying ideas and the attempt to hiring employees from other companies, hinder the value relationship between some companies. This leads to informal competition, difficulty in exchanging information, incipient mobilization, difficulty in maintaining loyalty and a dichotomous view on the participation of each agent in the cluster. However, those involved with the cluster know that a "joint participation is critical to the development of the industry" (Interviewee 7) because it fosters generation of value in the cluster.

Figure 4 Systemic structure - element "relationship"

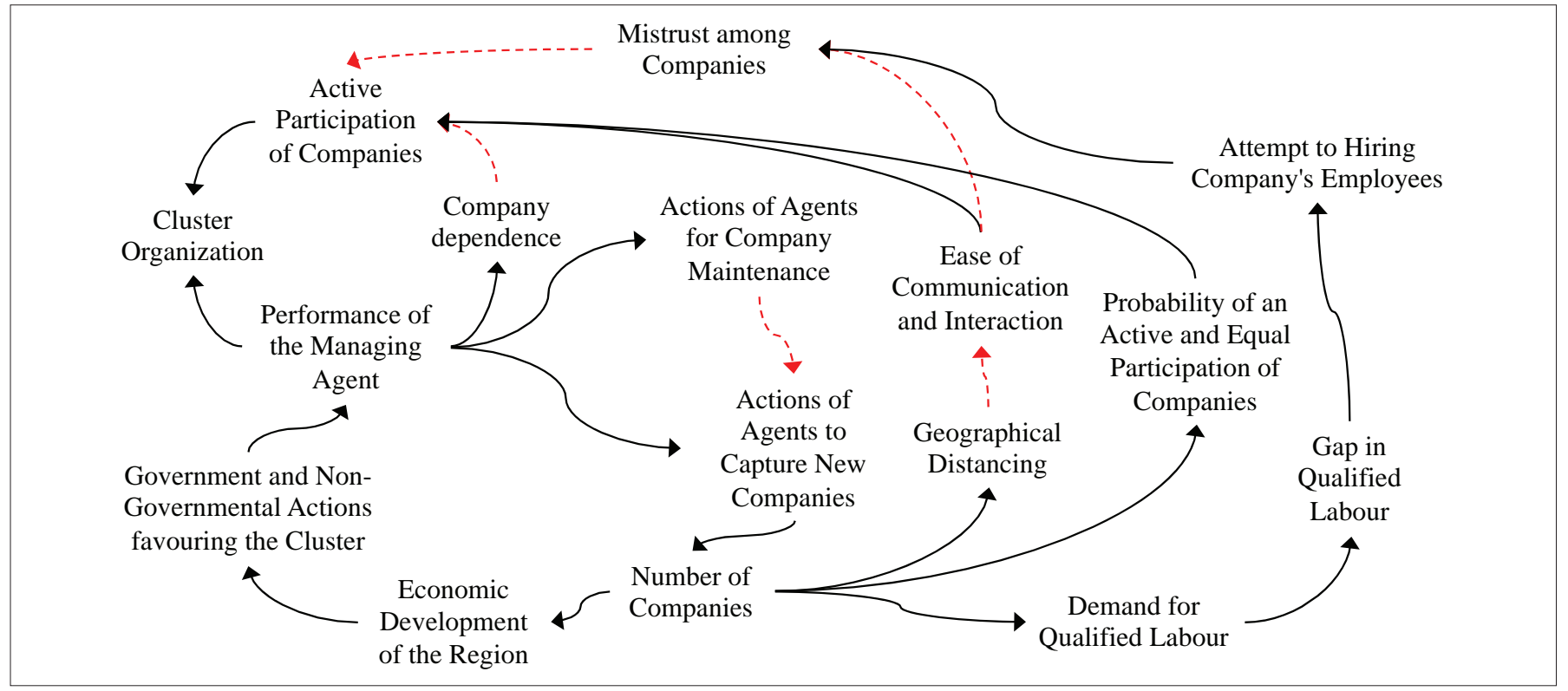

Upon analyzing the element "value metrics" (Figure 5), seeking and sharing of knowledge increases the development and use of value measurement metrics and, consequently, promotes the knowledge of customers' needs and the abilities to understand and respond to customers. Although the actions developed towards generation of value are mea- sured by cluster agents through feedback of participating companies, there is no follow-up after the end of actions. Interviewee 9 stresses that "follow-ups are not performed on the people trained in the courses". There is a misalignment of views by the cluster participants. The agents are satisfied with the developed service and companies do not 
agree with this positioning. For the Interviewee 4 (Company), there are "limitations of personnel and resources regarding the quantity of projects demanded" and the Interviewee 8 (Agent 2) has a conflicting view because he or she understands that "the actions developed are monitored; the needs of the companies are met; and which new actions should be developed are through of".

Figure 5 Systemic structure - element "value metrics"

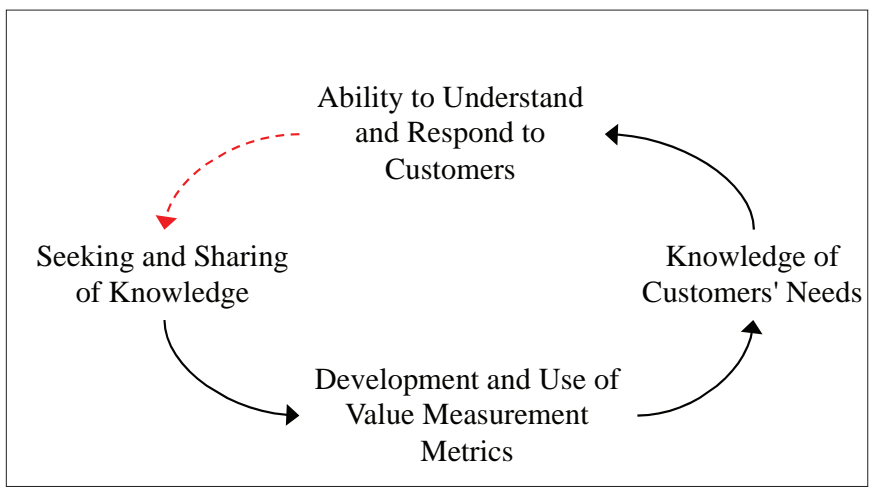

The element in Figure 6 called "internal capabilities" shows that by developing joint and focused actions there is an increasing in professional qualification and therefore in the ability to compete and respond to industry challenges. On the other hand, when performing a joint funding by performing joint fund-raising, the invested capital cost is lower. This allows investment resources to be destined to other areas, evidencing a trade-off. Thus, the driver element of value focuses on a joint work to foster and raise funds, professional training and prospecting for long-term actions using technical groups. Value-adding actions by companies are performed through meetings that aim the exchanging of experiences, courses, technical visits and certifications. The Interviewee 7 explained that "the cluster is divided into work groups, which comprise the process of researching demands in addition to analyzing and planning how to execute them". However, there is a dichotomous view of the market by smaller firms, which have difficulties in participating and implementing the proposed actions. This is because there is no sharing of internal capabilities and a scarce development of joint projects. Thus, the cluster agents observed that companies see the cluster as a provider and performer of actions, and not as an inducer of actions to be developed.

Figure 6 Systemic structure - element "internal capabilities"

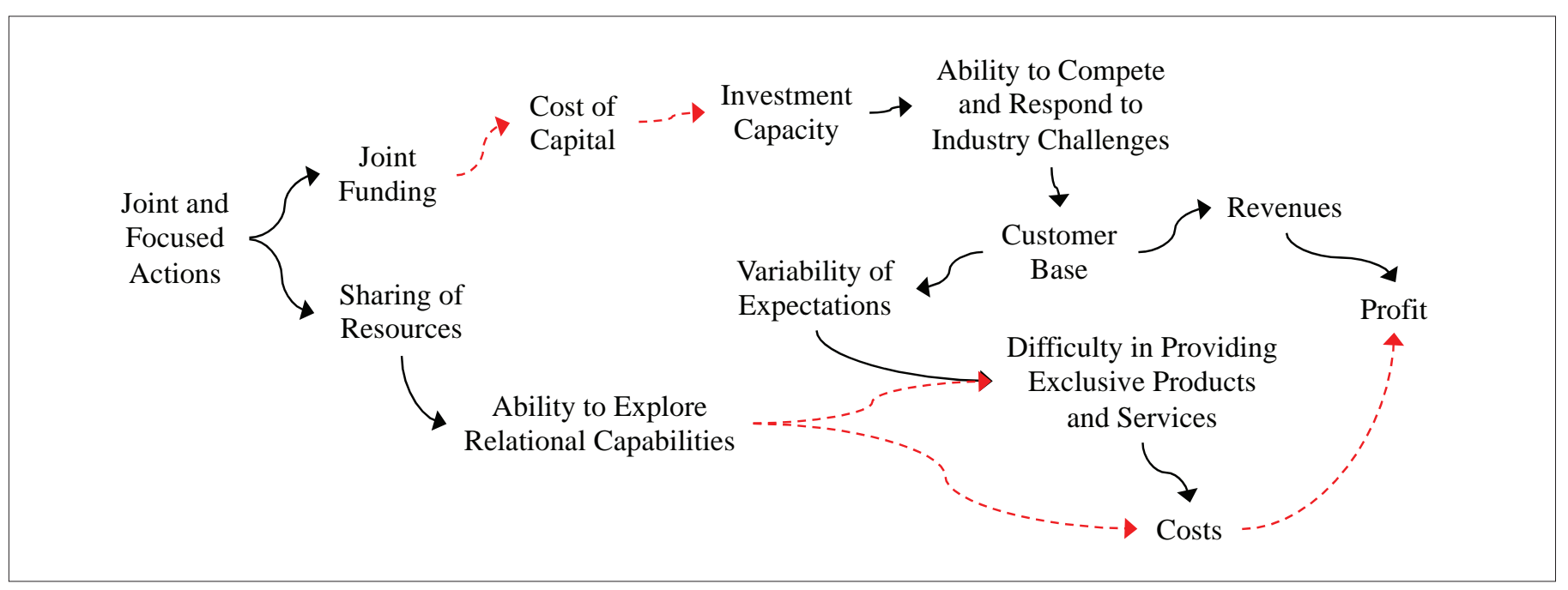

The elements "innovation" and "tactical focus and time horizon" have a influence in this cluster, since the fashion sector has a short product life cycle, which impacts on the market dynamicity and on the demand for innovation, generating a gap of innovation and influencing the ability to meet the needs of customers. Thus, as the variable formation of technical groups, which generates an increase in the cluster's ability of innovation, aids in cluster maintenance, in innovation of products developed, specific events and among other actions, as explained in Figure 7. Thus, "a collective work is performed to support companies focusing on the quality of the products developed"
(Interviewee 3). However, the heterogeneity of the participant companies (small, medium and large) results in actions focused on all segments. Companies do not perceive individual returns/gains. In addition, the agents stated that collective actions started by cluster agents are disseminated; however, the contrary does not occur. In other words, actions focused on innovation developed by companies are not disseminated inside the group. As a result, certain actions turn out to be repetitive because "companies act locally without a joint participation" (Interviewee 1). Thus, this causes loss of time in repeated and non-standard actions. 
Figure 7 Systemic structure - element "innovation"

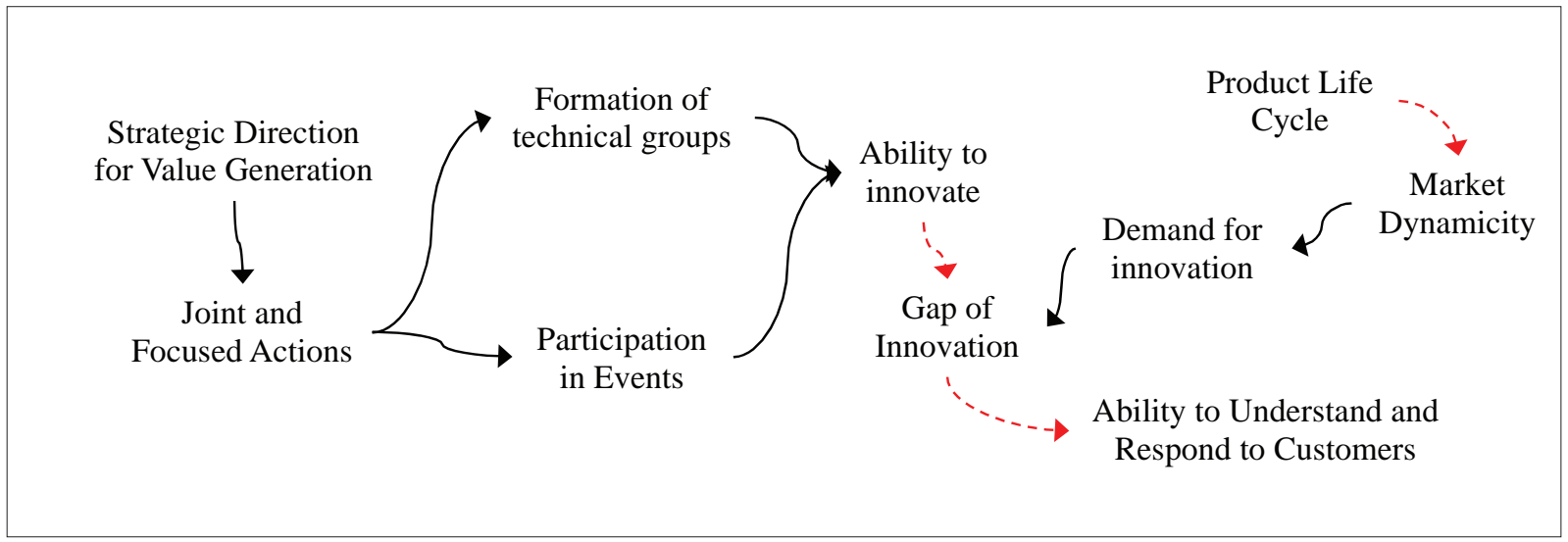

The companies of the cluster stated that products with short life cycles need differentiation, sustainability and management, as the element "tactical focus and time horizon" (Figure 8) represents. However, it is related to a low intensity of innovative creations by companies because "the fashion product cycle is indeed very short; our customers demand new products, and it is not easy for suppliers to meet our demands" (Interviewee 2). Therefore, "understanding the fashion market is complicated" (Interviewee 1). Finally, by analyzing the cluster, the relations can be punctual and/or continuous, varying according to the project and presenting both interventions.

Figure 8 Systemic structure - element "tactical focus and time horizon"

\begin{tabular}{|c|c|c|c|}
\hline $\begin{array}{c}\text { Market } \\
\text { Dynamicity }\end{array}$ & $\begin{array}{c}\text { Variability of } \\
\text { Expectations } \\
\text { Changing } \\
\text { Customer Needs } \\
\text { and Expectations } \\
\text { Knowledge of } \\
\text { Customers' Needs }\end{array}$ & $\begin{array}{c}\text { Difficulty in } \\
\text { Providing Exclusive } \\
\text { Products and Services } \\
\text { Ability to Understand } \\
\text { and Respond to } \\
\text { Customers }\end{array}$ & $\begin{array}{l}\text { Probability of } \\
\text { Product/Service to Fit } \\
\text { the Customer Needs }\end{array}$ \\
\hline
\end{tabular}

The Figure 9 shows the systemic structure complete. It uses different colors to represent the six elements defined in this research that contribute to the generation of value in the cluster as presented in Table 1. Beige represents value proposition, yellow represents value relation, blue represents value metrics, green represents internal capabilities, gray represents innovation, and pink represents tactical focus and time horizon.

By explaining the existing relationships in the cluster (Figure 9), the elements for value generation are systemically related. It is not possible to analyze and treat them in isolation. The structure that supports the behavior of the elements presents reinforcing and equilibrium relations that need to be understood for a correct intervention. In addition, some variables exert a significant influence by directing or hindering value returns to the cluster, that is, "cluster attractiveness". However, in order to boost cluster attractiveness, it is necessary to develop actions aiming the cluster's "generation of value for customers" as well as "generation of value for producers". In order to do so, it is fundamental that there be a "strategic direction for value generation". It can be obtained with an "active participation of companies" and "management agent performance", identified in this research as drivers. Thus, we obtain "amplitude and effectiveness of joint actions" and the consequent generation of the desired value.

It was also possible to identify among the variables in Figure 9 those that may hinder the cluster's generation of value, that is, being a barrier is the cluster's own growth. Thus, the greater the number of participating companies, the greater the difficulty for their needs to be met. This is important since the greater "cluster attractiveness" tends to increase the number of companies. This discussion will be expanded in the next section. In addition, since the fashion product has a "short life cycle", it requires companies to seek constant qualification to keep pace with market dynamics, which is not always made. Finally, the natural distrust in cooperating with competitors makes it difficult to carry out joint actions focused on generation of value. 


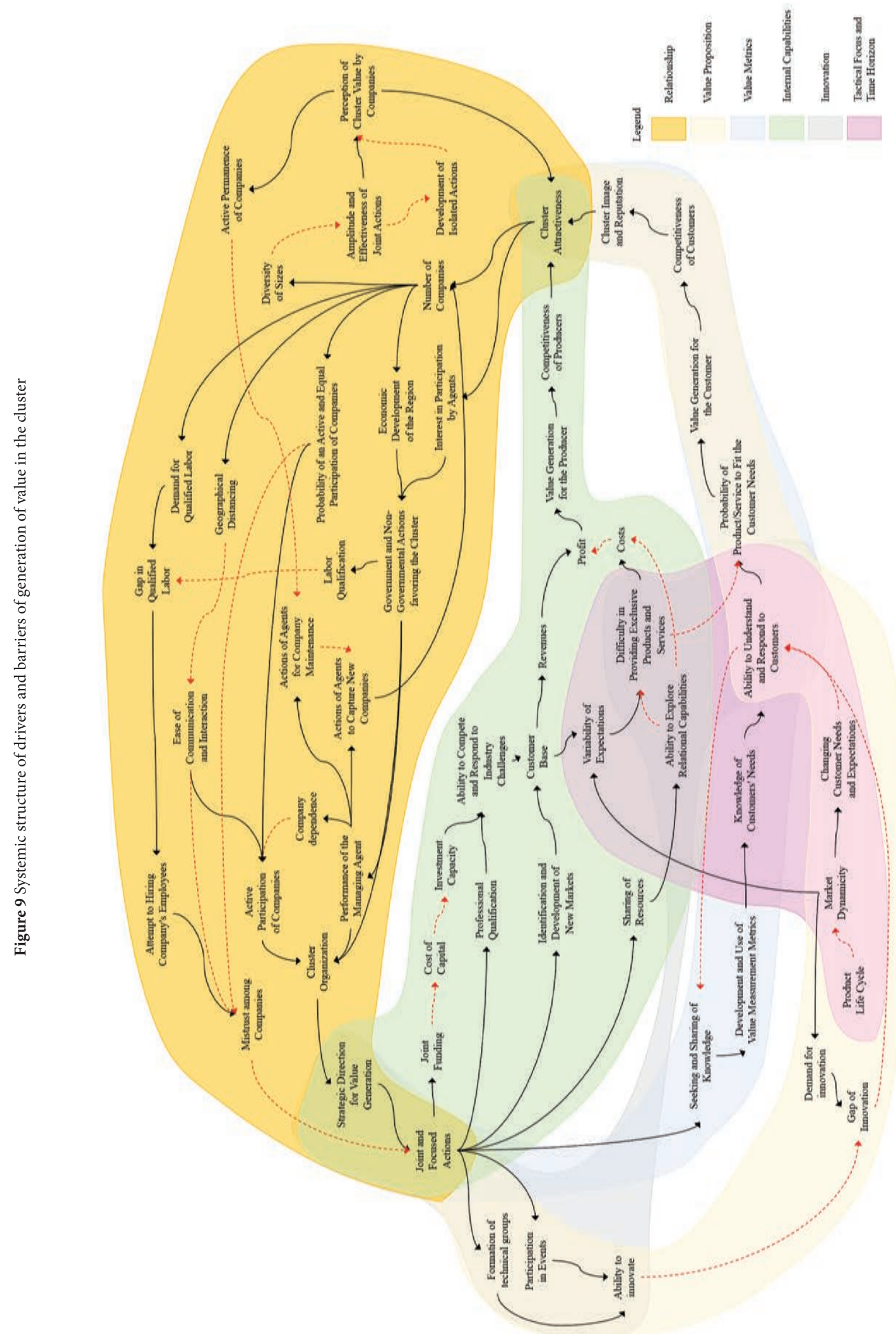




\section{Theoretical and managerial implications}

By analyzing the evidences arising from the systemic analysis, drivers and barriers for generation of value in industrial clusters may be confronted with the existing literature. Thus, the short life cycle of the fashion product is a problem for the dissemination of studies on generation of value. To minimize this barrier, frequent surveys are carried out with customers to identify their demands and needs. They guide the work of technical groups. In agreement with the researched literature, the agents of the cluster understand that generation of value is a process that begins by identifying needs and addressing the development of solutions, value delivery and monitoring (Corsaro, 2014; Kähkönen \& Lintukangas, 2012).

However, by addressing action monitoring companies involved with the cluster do not verify whether demands have been met. Thus, on the one hand, the companies surveyed did not identify their participation in the cluster as favoring the supply of value, because they stated that there is no concern with differentiating actions in function of representativeness. On the other hand, cluster agents verified that companies do not develop relationships. They valued offers among peers because companies understood that the cluster must "do something" for them and not that they are active participants in it. The main result is that the strengthening of bonds among peers, exchanging experiences and generating synergy among companies did not occur in a satisfactory way.

The development of innovative products and processes with partners (Lindgreen et al., 2012; Rodriguez et al., 2016) is not frequently evidenced. There was no evidence in interviews of an explicit concern with delivered values representing profit for companies participating in the cluster; conversely, the agents were concerned with the development of the companies as a whole, creating a collective competitive advantage.

In addition, the cluster understands that collaboration and combination of resources, skills and capabilities (Kähkönen \& Lintukangas, 2012) is a cluster concern. Although the word "trust" has been mentioned, the existence of strategies seeking to capture and maintain customers through collaborative work and management of offer of products and services in a collaborative way was not evidenced (Kähkönen \& Lintukangas, 2012; Wang et al., 2015). Only technological development projects are promoted collectively through events and technical visits. The transfer of knowledge among the cluster participants occur through technical groups. Although incipient, these actions agree with the literature, which points that the interaction between products and processes generates mutual benefits to those involved (Lindgreen et al., 2012).

The findings in the field also did not evidence that firms are seen as service providers. However, according to the literature, it is important to strengthen the credibility of manufacturing using service mechanisms (Kowalkowski et al., 2013) and interactions for the development of products and processes aiming mutual benefits (Lindgreen et al., 2012). Consequently, agents always promote the actions of the cluster. This evidences that companies do not operate in network without their presence. For most companies, being in a cluster is understood as getting help from the entity and not performing a collaborative work. This is confirmed upon the lack of partnerships among suppliers aiming to increase generation of value to companies.

Thus, companies consider the cluster as something external, of which they are only part. Thus, they do not perceive the existence of differences in their relations with suppliers inside or outside the cluster. Based on the observations, it is possible to conclude that exist two entities: the companies and the cluster. It is notorious that the companies' feelings indicate that they are not part of the cluster, but rather customers of the cluster. The study evidenced a conceptual misalignment by the participating companies regarding the true role of an industrial cluster. The relationship between companies seems to be transactional. Thus, the benefits resulting from the proximity between companies are not identified. However, according to the literature, generation of value is favored in function of proximity, companies act together to develop certain actions (Lindgreen et al., 2012). Therefore, the proximity relationship between companies and agents is stronger than among the companies themselves. This creates a natural distance since at no point in the research did the companies consider the possibility of sharing capabilities.

The literature identifies that brands seek to offer differentiation in a sustainable way to compete in the market (Beverland et al., 2007; Jeng $\&$ Yeh, 2016). However, the question of brand differentiation was not spontaneously mentioned by any of the interviewees. Examples are the brand "Polo de Moda de Caxias" (Caxias fashion hub), which represents an element for generation of value for the cluster. In this sense, it is relevant that none of the respondents mentioned it. A strategic directing for generation of value (Lindgreen et al., 2012) is not identified by anyone. Finally, it is possible to describe from interviews and the systemic analysis that the companies involved with the studied cluster "are not" an industrial cluster, but rather that they "have" an industrial cluster that promotes the development of the sector. Companies do not feel co-responsible for such development. They feel as merely beneficiaries of such development.

Such relationship among companies must be strengthened so that the results of the cluster are potentialized. There is a need to mitigate the companies' impression of cluster ownership, that is, all participate in this model and need to participate actively in it. In this sense, awareness talks and meetings of companies should aim to highlight the true objectives of an industrial cluster, i.e., improve the competitiveness of local companies participating in it (Fiol et al., 2011). Companies should actively be a part of the industrial cluster, and not just use it as a form of support. The cluster comprises all its members, and the synergy between them will bring better results for the whole. As described by Ikram et al. (2018), who analyzed supply clusters, horizontal and vertical connections in clusters result in synergistic benefits, that is, firms tend to exploit economies of scale by pooling their resources. Proximity speeds up an efficient inventory management. 
Finally, it is important to highlight that, due to the systemic nature of the relations, the actions that lead to the system objective, in this case the "cluster attractiveness", both strengthen the drivers and contribute to the strengthening of barriers. This behavior is consistent with the archetype "limits to growth", which advocates that the entire growth process finds its limits at some point (Senge, 2009). Understanding the existence of such limits is the first step in proposing new actions that minimize them. In this case study, it is necessary that the cluster organize in order to meet the demands of a growing number of participants with varied size and characteristics.

\section{Final considerations}

The final considerations of this study focus on achieving the main objective proposed, i.e., systemically analyze drivers and barriers for generation of value in an industrial cluster. The main barriers and drivers, from the point of view of the participants of an industrial cluster, were presented in Table 4 . The active participation of companies is required so that this dichotomy company/cluster is broken in order to design strategic actions for generation of value in industrial clusters.

In the cluster under study, there was no sharing of capabilities for the main activities of the company, that is, development and production. Sharing was observed only in support activities such as training, technical visits and research. Consequently, companies are missing the opportunity to collaborate with their peers. As a result, they become highly dependent on the actions promoted by agents. One of the causes of this lack of collaboration is a natural distrust in cooperating with competitors. It is a barrier for generation of value. Thus, the systemic analysis allowed explaining the relations that govern the behaviors observed in the field, in Section 4.

Regarding the theoretical basis for the conduction of this study, the literature does not address the identification of drivers and barriers for generation of value using the six elements described in three steps proposed by Lindgreen et al. (2012) and systemic analysis. Therefore, the analyses conducted in this study are a theoretical contribution. However, there were limitations such as the amplitude of the topic, i.e., the study did not perform an in-depth analysis of each element used to evaluate generation of value within a cluster. Initially, the need to work all elements in a unidimensional way was identified because cluster participants did not present such elements inside the cluster. Thus, it is interesting to perform an in-depth individualized analysis of each element of generation of value considering the analysis of this study.

The second limitation is the case study. The conclusions cannot therefore be generalized, and all results and analyses are limited to the object studied. Finally, the systemic analysis was performed taking into account the results of interviews and the literature. Other variables may have been neglected and/or considered as having too much influence in detriment of other variables with an equal influence. Aiming to verify whether the conclusions and results are similar in other industrial clusters, it is suggested that further studies be conducted in order to confirm the analysis conducted.

\section{Compliance with Ethical Standards}

Conflict of Interest: The authors declare no conflict of interest.

\section{Acknowledgments:}

Serrano, Rosiane, the author of this article is grateful to IFRS - Campus Erechim (Instituto Federal de Educação, Ciência e Tecnologia do Rio Grande do Sul - Campus Erechim) for the financial support to the development of this paper.

\section{References}

Allen, P., Maguire, S., \& McKelvey, B. (2011). The SAGE Handbook of Complexity and Management. SAGE Publications Ltd (1st ed.). London: SAGE Publications Ltd.

Associação Brasileira da Indústria Têxtil e de Confecção- ABIT. (2015). O Poder da moda: Cenários, Desafios e Perspectivas. Agenda de Competitividade da Indústria Têxtil e de Confecção Brasileira 2015 a 2018. Associação Brasileira da Indústria Têxtil e de Confecção- ABIT. Associação Brasileira da Indústria Têxtil e de Confecção- ABIT, São Paulo. Retrieved from www.abit.org.br

Battaglia, D., Schimith, C. D., Marciano, M. a., Bittencourt, S. a M., Diesel, L., Borchardt, M., \& Pereira, G. M. (2014). Creating value through services and relationships: The perception of purchasing companies. Procedia CIRP, 16, 26-31. http://doi.org/10.1016/j.procir.2014.01.004

Beverland, M., Napoli, J., \& Lindgreen, A. (2007). Industrial global brand leadership: A capabilities view. Industrial Marketing Management, 36(8), 1082-1093. http://doi.org/10.1016/j.indmarman.2006.08.007

Capra, F. (1985). Criteria of systems thinking. Futures, 17(5), 475478. http://doi.org/10.1016/0016-3287(85)90059-X

Carpinetti, L. C. R., Galdámez, E. C., \& Gerolamo, M. C. (2008). A measurement system for managing performance of industrial clusters. International Journal of Productivity and Performance Management, 57(5), 405-419. http://doi. org/10.1108/17410400810881854

Corsaro, D. (2014). The emergent role of value representation in managing business relationships. Industrial Marketing Management, 43(6), 985-995. http://doi.org/10.1016/j.indmarman.2014.05.011

Coutelle-Brillet, P., Riviere, A., \& des Garets, V. (2014). Perceived value of service innovation: a conceptual framework. Journal of Business \& Industrial Marketing, 29(2), 164-172. http://doi.org/10.1108/JBIM04-2012-0066

Espino-Rodríguez, T. F. (2016). How hotels compete on the basis of competitive priorities and their relationship with infrastructural and structural decisions. Service Business, 10(4), 737-773. http://doi. org/10.1007/s11628-015-0289-7 
Fiol, L. J. C., Tena, M. A. M., \& García, J. S. (2011). Multidimensional perspective of perceived value in industrial clusters. Journal of Business \& Industrial Marketing, 26(2), 132-145. http://doi. org/10.1108/08858621111112302

Ford, D. N., \& Sterman, J. D. (1998). Dynamic modeling of product development processes. System Dynamics Review, 14(1), 31-68. http://doi.org/10.1002/(SICI)1099-1727(199821)14:1<31::AIDSDR141>3.0.CO;2-5

Garriga, E. (2014). Beyond Stakeholder Utility Function: Stakeholder Capability in the Value Creation Process. Journal of Business Ethics, 4(120), 489-507. http://doi.org/10.1007/s10551-013-2001-y

Geraerdts, R. (2012). Customer value creation: A journey in the search of excellence. Industrial Marketing Management, 41(1), 11-12. http://doi.org/10.1016/j.indmarman.2011.11.023

Hair Jr, J. F., Celsi, M. W., Money, A. H., Samouel, P., \& Page, M. J. (2011). Essentials of Business Research Methods (2nd ed.). New York: Routledge.

Hau, L. N., \& Thuy, P. N. (2012). Impact of service personal values on service value and customer loyalty: a cross-service industry study. Service Business, 6(2), 137-155. http://doi.org/10.1007/s11628-011-0121-y

Hsu, M.-S., Lai, Y.-L., \& Lin, F.-J. (2014). The impact of industrial clusters on human resource and firms performance. Journal of Modelling in Management, 9(2), 141-159. http://doi.org/10.1108/JM2-112012-0038

IEMI - Inteligência de Mercado. (2016). Brasil Têxtil 2016. Retrieved August 28, 2017, from http://www.iemi.com.br/biblioteca/publicacoes-setoriais/brasil-textil/

Ikram, A., Su, Q., Fiaz, M., \& Rehman, R. U. (2018). Cluster strategy and supply chain management. Benchmarking: An International Journal, 25(5), 1302-1318. http://doi.org/10.1108/BIJ-06-2015-0059

Jeng, M.-Y., \& Yeh, T.-M. (2016). The effect of consumer values on the brand position of green restaurants by means-end chain and laddering interviews. Service Business, 10(1), 223-238. http://doi. org/10.1007/s11628-015-0266-1

Kähkönen, A.-K., \& Lintukangas, K. (2012). The underlying potential of supply management in value creation. Journal of Purchasing and Supply Management, 18(2), 68-75. http://doi.org/10.1016/j.pursup.2012.04.006

Karlsen, J. (2013). The Role of Anchor Companies in Thin Regional Innovation Systems Lessons from Norway. Systemic Practice and Action Research, 26(1), 89-98. http://doi.org/10.1007/s11213-012-9266-4

Kidwai, A., \& Saraph, A. (2016). Use of Archetypal Structures in Urban Dynamics. Systemic Practice and Action Research, 29(6), 583-595. http://doi.org/10.1007/s11213-016-9382-7
Kowalkowski, C., Witell, L., \& Gustafsson, A. (2013). Any way goes: Identifying value constellations for service infusion in SMEs. Industrial Marketing Management, 42(1), 18-30. http://doi.org/10.1016/j. indmarman.2012.11.004

Lacoste, S. (2012). "Vertical coopetition": The key account perspective. Industrial Marketing Management, 41(4), 649-658. http://doi. org/10.1016/j.indmarman.2011.09.013

Lei, H.-S., \& Huang, C.-H. (2014). Geographic clustering, network relationships and competitive advantage. Management Decision, 52(5), 852-871. http://doi.org/10.1108/MD-08-2013-0426

Liao, T.-J. (2010). Cluster and performance in foreign firms: The role of resources, knowledge, and trust. Industrial Marketing Management, 39(1), 161-169. http://doi.org/10.1016/j.indmarman.2008.08.003

Lindgreen, A., Beverland, M. B., \& Farrelly, F. (2010). From strategy to tactics: Building, implementing, and managing brand equity in business markets. Industrial Marketing Management, 39(8), 1223-1225. http://doi.org/10.1016/j.indmarman.2010.02.018

Lindgreen, A., Hingley, M. K., Grant, D. B., \& Morgan, R. E. (2012). Value in business and industrial marketing: Past, present, and future. Industrial Marketing Management, 41(1), 207-214. http://doi. org/10.1016/j.indmarman.2011.11.025

Lindgreen, A., Palmer, R., Vanhamme, J., \& Wouters, J. (2006). A relationship-management assessment tool: Questioning, identifying, and prioritizing critical aspects of customer relationships. Industrial Marketing Management, 35(1), 57-71. http://doi.org/10.1016/j.indmarman.2005.08.008

Lindgreen, A., \& Wynstra, F. (2005). Value in business markets: What do we know? Where are we going? Industrial Marketing Management, 34(7), 732-748. http://doi.org/10.1016/j.indmarman.2005.01.001

Manfredini, M. L., Speggiorin, A., Balbinot, A., Mattioda, E., Venson, B. S., \& Thomé, M. L. (2013). Plano de Desenvolvimento de arranjos produtivos locais APL Polo de Moda da Serra Gaúcha. Uma ética para quantos? Universidade de Caxias do Sul, Caxias do Sul.

Marshall, A. (1920). Principles of Economics. Library (8th ed.). London: Macmillian and Co. Retrieved from http://scholar.google.com/ scholar?hl=en\&btnG=Search\&q=intitle:Enquiries+Concering+Hum an+Uderstanding\# 1

Miles, M. B., Huberman, A. M., \& Saldanã, J. (2014). Qualitative Data Analysis: a methods sourcebook (3rd ed.). Arizona: SAGE.

Morandi, M. I. W. M., Rodrigues, L. H., Lacerda, D. P., \& Pergher, I. (2014). Foreseeing Iron Ore Prices Using System Thinking and Scenario Planning. Systemic Practice and Action Research, 27(3), 287-306. http://doi.org/10.1007/s11213-013-9277-9 
Mudambi, R., Mudambi, S. M., Mukherjee, D., \& Scalera, V. G. (2017). Global connectivity and the evolution of industrial clustersFrom tires to polymers in Northeast Ohio. Industrial Marketing Management, 61, 20-29. http://doi.org/10.1016/j.indmarman.2016.07.007

Niu, K., Miles, G., Bach, S., \& Chinen, K. (2012). Trust, learning and a firm's involvement in industrial clusters: a conceptual framework. Competitiveness Review, 22(2), 133-146. http://doi. org/10.1108/10595421211205976

Polo Penã, A. I., Frías Jamilena, D. M., \& Rodríguez Molina, M. ?ngel. (2017). The effects of perceived value on loyalty: the moderating effect of market orientation adoption. Service Business, 11(1), 93-116. http://doi.org/10.1007/s11628-016-0303-8

Porter, M. E. (2000). Location, Competition, and Economic Development: Local Clusters in a Global Economy. Economic Development Quarterly, 14(1), 15-34. http://doi.org/10.1177/089124240001400105

Rodriguez, M., Doloreux, D., \& Shearmur, R. (2016). Innovation strategies, innovator types and openness: a study of KIBS firms in Spain. Service Business, 10(3), 629-649. http://doi.org/10.1007/s11628-0150286-x

Schneider, K., \& Hoffmann, I. (2011). Potentials of Qualitative Modeling of Complex Health Issues. American Journal of Health Behavior, 35(5), 557-567. http://doi.org/10.5993/AJHB.35.5.5

Sellitto, M. A., \& Luchese, J. (2018). Systemic Cooperative Actions among Competitors: the Case of a Furniture Cluster in Brazil. Journal of Industry, Competition and Trade, 18(4), 513-528. http://doi. org/10.1007/s10842-018-0272-9

Sellitto, M. A., Pereira, G. S., Marques, R., \& Lacerda, D. P. (2018). Systemic Understanding of Coopetitive Behaviour in a Latin American Technological Park. Systemic Practice and Action Research, 31(5), 479-494. http://doi.org/10.1007/s11213-017-9439-2
Senge, P. M. (2009). A quinta disciplina: arte e prática da organização que aprende (25th ed.). Rio de Janeiro: BestSeller.

Serrano, R. (2013). Utilização do Pensamento Sistêmico e Planejamento por Cenários em setores produtivos: uma aplicação no setor de vestuário na região do Alto Uruguai. Dissertação de Mestrado- Programa de Pós Graduação em Engenharia de Produção e Sistemas da Universidade do Vale do Rio dos Sinos- UNISINOS, São Leopoldo.

Serrano, R., Lacerda, D. P., Cassel, R. A., Rodrigues, L. H., \& Soares, P. F. (2017). Systemic Analysis of the Soccer (Football) Value Chain: Learning from the Brazilian Context. Systemic Practice and Action Research. http://doi.org/10.1007/s11213-017-9425-8

Sobh, R., \& Perry, C. (2006). Research design and data analysis in realism research. European Journal of Marketing, 40(11/12), 1194-1209. http://doi.org/10.1108/03090560610702777

Sterman, J. D. (2002). System dynamics: systems thinking and modeling for a complex word. In ESD Internal Symposium (p. 31). Cambridge: Massachusetts Institute of Technology Engineering Systems Division. Retrieved from https://esd.mit.edu/WPS/internal-symposium/esd-wp-2003-01.13.pdf

Wang, J., Lai, J.-Y., \& Hsiao, L.-C. (2015). Value network analysis for complex service systems: a case study on Taiwan's mobile application services. Service Business, 9(3), 381-407. http://doi.org/10.1007/ s11628-014-0237-y

Zare Mehrjerdi, Y. (2012). Library expense control: a system dynamics approach. The Electronic Library, 30(4), 492-506. http://doi. org/10.1108/02640471211252201

Zeng, S. X., Liu, H. C., Tam, C. M., \& Shao, Y. K. (2008). Cluster analysis for studying industrial sustainability: an empirical study in Shanghai. Journal of Cleaner Production, 16(10), 1090-1097. http:// doi.org/10.1016/j.jclepro.2007.06.004 


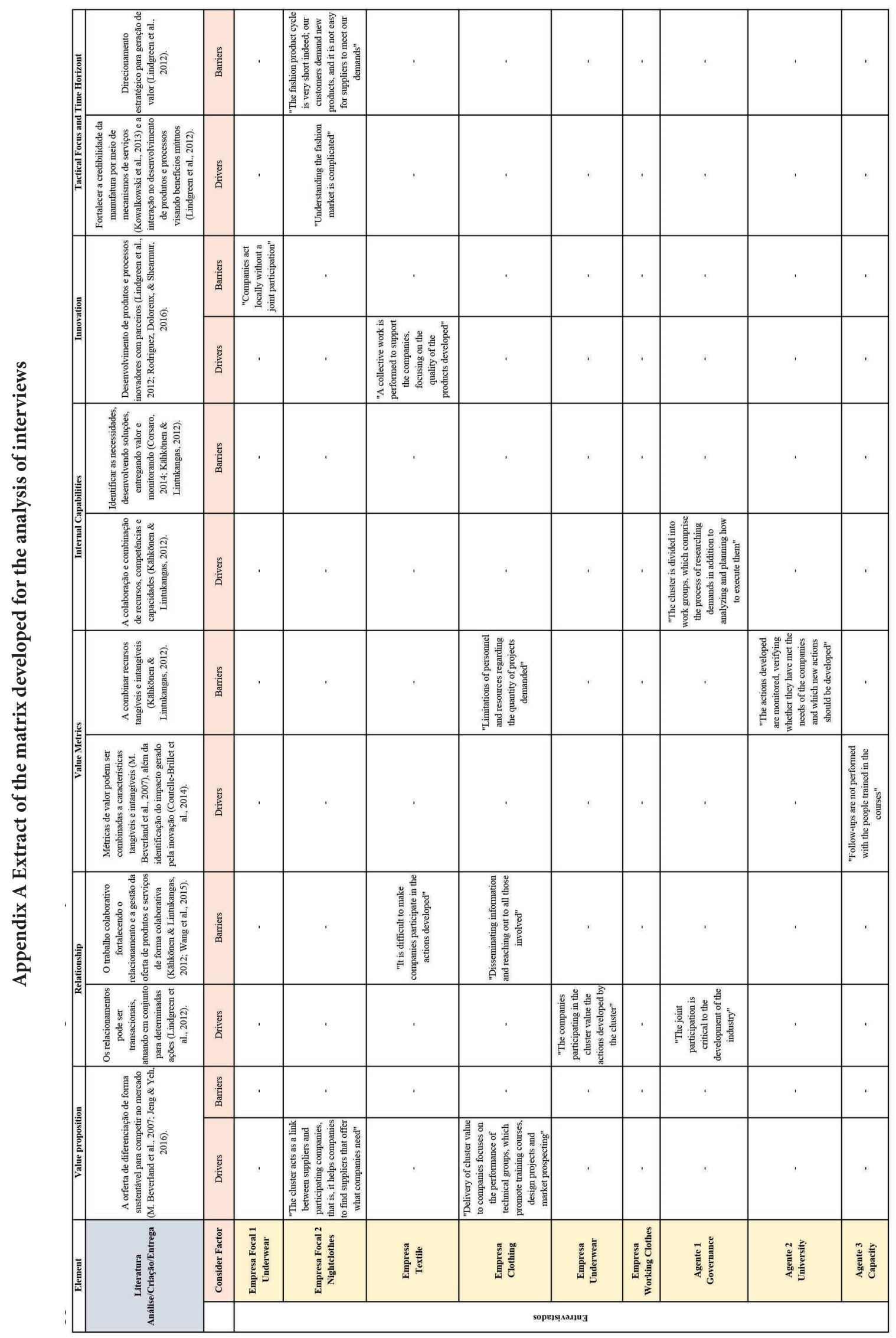


